\title{
teaching political science in europe
}

\author{
mike goldsmith and chris goldsmith * \\ Department of Public Policy, De Montfort University, Leicester LE1 9BH, UK \\ ${ }^{\star}$ Corresponding author.
}

doi:10.1057/eps.2010.38

\begin{abstract}
This article first reviews the history of political science teaching in Europe before going on to consider a range of recent developments in the teaching of political science, including cross-national joint programmes; technologically enhanced learning; placement learning and problem-based learning. The last section considers a range of issues facing political science teachers, including financial pressures; EU and national government policies; Bologna and quality assurance. The article concludes by suggesting that particular attention needs to be paid to what is taught at master's and doctoral levels.
\end{abstract}

Keywords politics teaching; developments; issues

W hile politics has been taught since the time of Aristotle and Plato, political science teaching has a much shorter history. This article first examines briefly the history of teaching political science in Europe, discusses some recent teaching developments and finally reviews some issues facing political science teaching in Europe today.

\section{TEACHING POLITICS AND POLITICAL SCIENCE - A BRIEF HISTORY}

National and international stocktaking of political science as a discipline has been an activity in which professional political scientists have occasionally engaged over the last 40 years. ${ }^{1}$ But reviewing its teaching has only attracted attention more recently, for two reasons. Within the discipline, teaching has always been seen as 'less glamorous' than research, albeit that most professional political scientists teach more than they research. Externally, the discipline has faced similar pressures to those facing higher education (HE) as a whole. Political science now competes for students globally. Dependence on public funding for universities means governments want universities to achieve certain policy objectives, whatever they may be. Therefore, political science and political scientists are subject to the same pressures of benchmarking the discipline, 
assessing research performance and increasing international cooperation as are other disciplines. And in the European context, the EU has brought other pressures, either as a result of the Bologna agreement, or increasing efficiency within the European and international market, or whatever.

The teaching of political science is largely a late twentieth century development. It was really only in the late nineteenth century that the discipline was established, following the creation of the first schools of political science in New York, London and Paris. Even then, it was largely politics and not political science that was taught, mainly alongside philosophy or law. Such courses were designed to train public servants rather than to foster a separate science - the emphasis being on national constitutions, institutions and practices, and on political philosophy. It was not until after the Second World War that the teaching of politics and political science in Europe really blossomed. By 2005, Klingermann estimated there were more than 300 universities teaching politics to more than 150,000 students (Klingermann, 2007: 23).

The creation of national professional bodies and of the European Consortium for Political Research (ECPR) underpins the development and spread of political science teaching in Europe, together with the expansion of student numbers in HE. In addition, the determined efforts of a few individuals in establishing the discipline cannot be underrated. For example, in the UK, the discipline owed much to the efforts of people like Norman Chester, and Bill Mackenzie; in France, Maurice Duverger and George Veddel were important in 'giving the discipline institution recognition' (Déloye and Mayer, 2008: 3); and in Italy, the establishment and development of politics teaching owed much to people like Giovanni Sartori, Georgio Freddi and others.

\section{'... teaching has always been seen as "less glamorous" than research, albeit that most professional political scientists teach more than they research'.}

It is much more difficult to provide an accurate picture of the spread of political science teaching in Central and Eastern Europe following the break-up of communism. While some politics was taught in most of the Central and East European countries before 1989, it was dominated by Marxist-Leninist thought and by the communist regimes in place. Following the break-up of communism, the influence of George Soros and his Open Society movement undoubtedly helped the spread of new political science teaching, both by providing opportunities for western scholars to teach in Central and East European institutions and for graduate students to receive their training outside the former communist bloc. ${ }^{2}$ The discipline's growth in these countries has been steady over the last 20 years, though we have only estimated figures for the number of political science teachers and students. For example, Klingermann et al (2002: 17) report some 160,000 students in the then ten EU accession countries alone, and Klingermann (2008: 376) further estimates 168 universities in Central and Eastern Europe teaching political science with some 4,000 academic staff.

\section{INNOVATIONS IN TEACHING POLITICAL SCIENCE}

Until recently, European political science has depended on two key teaching 
methods: the lecture and the seminar or tutorial. Lectures have been a staple of university teaching since the fourteenth century and remain the dominant method for teaching large groups of students. In Britain, lectures are usually supported by seminars or tutorials on a weekly or fortnightly basis where smaller groups of students can discuss readings or ideas raised in the lecture. Yet, in the rest of Europe such a clear distinction may not exist: a seminar may be a course of lectures assessed by a written paper rather than an examination. With such differences in basic teaching methods, it is no surprise that innovations in teaching practice within the discipline are not uniformly distributed across the continent. However, the forces driving change affect all institutions within the European Higher Education Area equally. These include the challenge of maintaining the quality of provision in the face of growing student numbers; the demand on universities to address not only the academic needs of students, but also to prepare them for the labour market; and, finally, the necessity to adapt pedagogy to new developments in information and communication technology.

Political scientists are well-placed to respond to these pressures with a critical eye. Certainly, some level of resistance to these pressures is a healthy sign of academic freedom and continued commitment to education as a good in itself. However, the profession has begun to address teaching and learning more effectively. As is often the case, the American Political Science Association has been at the forefront of developments, its annual Teaching and Learning Conference bringing together teachers of political science from across the world and providing a venue for developing and disseminating innovative practice. This model has been replicated to a limited extent in Europe by EpsNet (now part of ECPR), although teaching and learning should have a higher profile within the European profession. At the national level, some professional associations have set up Teaching and Learning Specialist Groups. Furthermore, the availability of national and European seed funding has facilitated the development of a wide range of approaches to teaching politics. Here we focus on four broad areas of innovation: joint programmes, technology-enhanced learning, placement learning and problem-based learning.

\section{JOINT PROGRAMMES}

Joint cross-national programmes are increasing in number. Examples include a long-established jointly recognised cooperative programme between Bordeaux and Stuttgart at all levels. MUNDUSMAPP is a consortium of universities in Hungary, Spain, the Netherlands and the United Kingdom offering a joint master's programme in Public Policy. ${ }^{3}$ At doctoral level, the GEM doctoral school brings together nine HE institutions to encourage research on the European Union and global governance, the collaboration being built on the foundation developed in establishing the GARNET network of research excellence. ${ }^{4}$ The limited opportunities offered to doctoral students as part of the EU's Framework research initiatives have been important in providing excellent training at that level. But again dissemination of good practice is relatively slow across the discipline as a whole, despite the increasing opportunities for students to study abroad.

\section{TECHNOLOGY-ENHANCED LEARNING}

The development of the internet has fundamentally and radically expanded the amount of data available to students and scholars alike. Current students are more likely to be used to reading on screen than reading a book: the mastery 
of library and bibliographic skills that served their tutors so well is often seen as redundant. Today's students may see little point in listening to a lecture on development issues in Africa when they can watch a YouTube video posted by aid workers on the ground. Furthermore, mobile technology developments mean that the screen is often in the student's pocket. These changes result in the role of teachers and universities evolving: we now guide students through the mass of voices and information available and provide them with the skills to discern good information from bad, rather than being the primary providers of information.

Most obviously, technology has been used to enhance the teaching of political science through the provision of virtual learning environments (VLE). ${ }^{5}$ These allow tutors to provide students with supporting materials, exercises and discussion forums in order to structure their independent learning experience more effectively. In reality the VLE becomes an extension of the classroom, allowing lecturers to continue the lesson outside formal teaching time. Teaching can thus be undertaken at a distance, and accessed at any time - lessons offered in class can then be reinforced at home. Yet, making information too readily available may reduce students' opportunities to develop important skills in evaluating information resources and become independent learners. While this is a concern, as technology transforms our access to information, the skills necessary to study political science are changing as well.

VLEs are basically a convenient and dynamic tool for delivering course materials to students. They are normally closed systems only accessible to students enrolled at a particular institution. One consequence is considerable replication of effort, as core topics of the political science curriculum such as Introduction to Politics, Political Analysis and Research Methods are taught as part of nearly every undergraduate programme throughout Europe. One response has been the development of projects to share resources. The PARLE project, for example, has developed a state-of-the-art research methods course for postgraduate students, allowing students to access a series of tutorials that enable them to learn about both practical research methods like discourse or quantitative analysis, together with the epistemological and ethical issues involved in their use. Initially available as a DVD, it is now a web-based project. A similar approach has been taken by another consortium based at the University of Southampton (POLIS) with a focus on the teaching of citizenship issues. Another example is the International Relations and Security Network, based at the Swiss Federal Institute of Technology, which provides both a portal for international relations news as well as e-learning materials on intelligence and security issues.

With the encouragement of the European Union, such consortia have rapidly spread across Europe, sharing teaching expertise and developing shared resources. The e-LERU project, ${ }^{7}$ for example, brings together the universities of Geneva, Heidelberg, Helsinki, Zurich, Leuven, Strasbourg and the Stockholm Karolinska Institute together in a virtual campus, where students can take online modules at bachelor, master's and doctoral levels developed by lecturers at the participating institutions. Participating students effectively undertake 'virtual mobility', developing experience of working with different academic systems while remaining in their home institutions. Another approach can be seen in the work of the NewSecEU consortium of Technical University Dresden, Charles University Prague, University of Wroclaw and Leicester's De Montfort University. Here partners have developed a shared module examining issues in European Security, 
including energy security, the European Neighbourhood policy and asylum and migration policy. However, the project's main goal is to make use of Web 2.0 collaboration and communication tools to develop student skills in collaborative research. Using discussion forums, wikis and other communication tools, students are involved in writing research papers in multinational teams, eventually presented publicly in Prague in April 2010. Again technology enhances the student learning experience, providing them with content, specialist teaching and experience of international collaboration, something not accessible using traditional teaching methods.

\section{PLACEMENT LEARNING - THE DRIVE FOR EMPLOYABILITY SKILLS}

As Europe drives towards a knowledge economy, universities have a key role in providing students with the skills necessary to contribute. Work placements are one way of developing these skills. Placement learning has a long tradition within European universities. Some courses include an extra year during which the student may act as an intern for a legislative member, work in sub-national government or a quasiautonomous non-governmental organisation (QUANGO). Often not formally assessed, this work experience has frequently been focussed on the skills students can acquire and the networks they can build rather than the subject matter of political science.

However, recent scholarship ${ }^{8}$ has argued that political science educators should think about placements in a different way. Work placements can provide an opportunity for students to investigate the relationship between political theory and practice. By structuring placements as part of other modules, students can experience real-world involvement in the

\section{'As Europe drives towards a knowledge economy, universities have a key role in providing students with the skills necessary to contribute'.}

research process, while also developing insights in the discipline's core subject matter. But there are many challenges for teaching teams to overcome in organising placements within the undergraduate curriculum, including practical issues about placement organisation (health and safety training, travel costs, management of partners) and pedagogical issues such as where to fit placements in a three-year undergraduate programme; whether to assess the practical experience, or to make the placement part of a piece of research. Nevertheless, the undoubted popularity of these opportunities and their considerable potential for academic learning and self-improvement makes them a growing feature of the politics curriculum for the foreseeable future.

\section{PROBLEM-BASED LEARNING: CASES AND SIMULATIONS}

There are other methods by which students can develop their learning in a work relevant way, while deepening their disciplinary knowledge. We may label this approach problem-based learning, an approach to teaching that has a long history in business, law and medical education. Small groups of students are presented with problems drawn from real-world experience and asked to analyse the issues and draw conclusions about them. The goal is to produce students who are 'independent, enterprising problem solvers' rather than passive consumers of knowledge. 
Problem-based learning can be introduced into the politics classroom through the use of the case method. Tutors prepare a number of scenarios based on cases drawn from real life, perhaps based on stories drawn from interviews with former and current politicians and civil servants - or simply the result of the teacher's creative thinking. Whatever the source, such cases should be relatively brief and not require too much prior knowledge, so that students can debate them relatively quickly. In general, cases are best suited to discussion over 1 or 2-hour long classes. They provide an easy way into discussions of complex theoretical and philosophical questions. For example, the University of York offers case studies on issues as broad as what is democracy, the place of the security services in a democratic society and the future of feminism. ${ }^{9} \mathrm{~A}$ grander version of this approach is the simulation game, which requires a much deeper level of preparation and engagement. Students participate in a recreation of a typical real-world situation and have to react to the scenario according to their allocated role. In political science, simulations tend to focus around either crisis management or negotiation scenarios. Several institutions ask their students to participate in Model United Nations or in simulated European Council negotiations, representing the interests of different countries.

Case studies and simulations require both teachers and students to change from their ordinary roles in the classroom. Greater involvement is demanded of the student, who takes an active part in the creation and interpretation of knowledge rather than passively receiving it. Students must learn facts and remember them, while processing information and manipulating it on a deeper level. Furthermore, such learning is not dependent on the tutor: it can be independent, or collaborative with other students. The teacher's role is also altered: s/he acts as a facilitator of learning rather than a provider of knowledge, prompting discussion with questions, clarifying issues in which there is confusion and directing students to potential solutions.

\section{ISSUES IN TEACHING}

Several issues impact on the teaching of political science. First, there are the continuing activities of national/regional governments in relation to HE as a whole. The phrase 'do more for less' generally sums up the attitude of most governments and such an attitude is unlikely to change radically in future. Nor is the subject's popularity among students likely to decline drastically. These features, together with studies suggesting that there is an overproduction of doctoral students for the academic labour market in the subject (Goldsmith, 2005), mean there will be continuing pressure on staff-student ratios. Consequently, there is a continuing need for innovation in teaching methods and for the crossnational dissemination of good teaching practice.

Other government policies also impact on political science teaching. Increasingly, HE institutions are encouraged to diversify funding streams; to produce market-oriented innovations; and also to develop students with the 'right mix' (whatever that may be) of skills for employment. This 'right $\mathrm{mix}^{\prime}$ of skills means that students need more and more professional qualifications beyond a simple first degree. At one level, the Bologna developments recognise this trend, even if they are also concerned with securing comparability in the time taken for students to reach certain levels of attainment. ${ }^{10}$ Within Europe, given the generally longer time period required to reach doctoral level in most countries outside the UK, Bologna may lead to a situation in which it is the master's degree 
that becomes the job market entry level qualification - which also fits well with the market pressures for the 'right $\mathrm{mix}^{\prime}$ of skills. Increasingly, students stay on to master's level: we can expect their numbers to increase, and for them to demand for more specialist (relevant) courses at this level.

But Bologna is not just about shortening the time students spend in HE. It, and other initiatives emanating from Brussels, has been concerned with matters of curriculum, with portability of qualifications and with student mobility. All have had an impact on political science teaching and we have illustrated some developments above. Some cross-national cooperation has led to a debate about the nature of the curriculum (for example, through the activities of Epsnet and the European Conference of Political Science Associations); others have led to new innovations in teaching methods and in course development. Nowadays most students can spend at least one semester studying outside their own country. An increasing number of institutions offer some or all or their teaching in English, especially at the master's level (European Universities Association (EUA), 2007). EUA (2007: 33) also reports that around 60 per cent of $\mathrm{HE}$ institutions now have joint programmes at one of the three Bologna cycles. Teachers are increasingly involved in European wide networks, often funded by the EU, but their work is not well publicised or disseminated, so that the benefits of this work are not widely shared. In curriculum development matters, one result is that teachers are forever running the danger of re-inventing the wheel.

Should there be a core curriculum for political science? Some agreement exists on what constitutes the core elements a political science first degree should cover, though little on the topics to be covered in each element, and whether or not all
'... there is a continuing need for innovation in teaching methods and for the cross-national dissemination of good teaching
practice'.

programmes should contain all elements, ${ }^{11}$ as suggested by the European Conference of National Political Science Associations in 2003.12 In our view, at first degree level, such issues are not a problem, especially if the first degree is regarded as a general rather than specialist qualification, provided the quality and standards of such degrees are broadly comparable. A wide choice of subjects in an undergraduate degree is not a problem for US political science, or for those European students who spend time in the United States, provided that the level of attainment and standards reached on courses outside the institution or home degree programme is comparable with the standards set within the home institution. European political science teachers now have wide experience of comparing student attainment, given the long history of Erasmus exchanges. But again this experience is likely to be individually or institutionally specific rather than widely shared. ${ }^{13}$

Student mobility is a central plank of the Bologna process, with 20 per cent mobility the aim by 2020 . Some programmes, such as that at Sciences-Po in Paris, already require their students to spend a year abroad and to follow courses in two foreign languages during their programme, but recognise that it is difficult to evaluate the year abroad. Other countries offer part or all of their courses in English (especially at master's level) in the hope of attracting Englishspeaking students and of increasing their 
students' marketability on graduation. ${ }^{14}$ Certainly, the opportunity to study abroad, and/or to gain some practical work experience may well be increasingly sought by would-be students. ${ }^{15}$

Such developments raise the issue of quality and standards. In an ever increasingly competitive market for students, the 'customer' has every right to expect the highest quality teaching, maintained wherever s/he studies. While at undergraduate level the 'student experience' may well be more than simply what is followed in the classroom, and that what a student learns in a Manchester bar is as valuable as that learnt in an Amsterdam café, it is important that what $s / h e$ receives in the classroom is of high quality. We suspect most political science teachers could tell of 'horrific experiences' of their students when studying abroad or from some work experience, yet little effort is taken to ensure that such experiences are avoided in future, beyond perhaps dropping the odd institution from the (ever growing) list of foreign and work placement partners.

For us, the situation is more important at postgraduate level. Master's level programmes are increasing, more are open to foreign students, more taught in English, and many developed in response to some perceived 'gap' in the market, possibly in collaboration with some other subject area. ${ }^{16}$ While many joint (crossnational) programmes are subject to the quality assurance programmes of the institutions concerned, doubts must remain about how effective such oversight can be in practice. Regular external peer review of such programmes is needed. Teachers need to develop the expertise necessary to undertake such review work. Some form of cross-national benchmarking activity against which such reviews can be judged is also desirable. Such a development is even more important at doctoral level, especially for those programmes designed to provide

\section{'... the "student experience" may well be more than simply what is followed in the classroom ... what a student learns in a Manchester bar is as valuable as that learnt in an Amsterdam café'}

the kind of training the profession deems necessary to gain a post in a $\mathrm{HE}$ institution. ${ }^{17}$

The issue of quality and standards has been widely recognised by the European Union and national governments. There are two related issues here. First, at national level, there is the question of how detailed the assessment of quality and standards of teaching and programmes should be: a light touch regime (in which responsibility fairly and squarely lies with the institution) or more detailed and possible heavy-handed (in which some national body undertakes the assessment and produces a public report on each programme). The former may well leave some underperforming institutions undiscovered, while the latter may take on a bureaucratic nature in which 'ticking the boxes' becomes as important as the actual teaching performance in the classroom. ${ }^{18}$ Striking the balance between the two is desirable, but difficult to attain.

This problem becomes even more acute at the European level, as discussions undertaken within the formal Bologna process since 1999 illustrate. ${ }^{19}$ Largely concerned with creating national frameworks within a European framework, there has been pressure on member countries to adopt a national assessment body along the lines of those found in the 
UK, the Netherlands and Denmark. The (in)famous $3+2+3$ three-cycle degree pattern has been widely adopted, with the EUA estimating some 82 per cent of institutions having adopted it, meaning a shift generally from a pattern of education based on the German system to one closer to that found in the UK or the USA. First and master's levels are defined in terms of the number of credits required (180 for a B.A., 120 for a master's). An increasing number of institutions have adopted the European Credit Transfer and Accumulation (ECTS) credit system. EUA (2007: 37-38) reports 75 per cent of institutions using it, and 66 per cent use ECTIS solely as the basis for assessing progress on courses and awarding degrees, though some countries (e.g., the UK, Spain, Sweden, Greece and Russia) do not use the system in this way. Designed to suggest that a top qualification from university $A$ is equivalent to that from university $B$, or that graduates from both universities, who may well have taken courses at universities $D, E$ and $F$ in three other countries, are qualified for doctoral work at university $\mathrm{C}$ in yet another country! These changes result in increased pressure on those responsible for student admissions to ensure that the qualifications are adequate, and that the product does what it says on the package. This issue is made more difficult by the fact that implementation of the Bologna process is something that 'appears to be a single European process (which) is thus altered by the variety of national contexts in which it takes place' (EUA, 2007: 22).

At stake here is not only the problem of maintaining the standards and quality of political science teachers and researchers as a whole, but also the reputation of graduates in political science in the wider job market. Here the concern is with the specific and generic skills that political science graduates have at each of the three levels. Perhaps the issue is more important at the master's level, with more students seeking to secure a master's qualification. Such a pattern seems likely in many European countries other than the $\mathrm{UK}^{20}$ since it would be closer to the general pre-Bologna practice of students taking up to 5 years (or more) to graduate.

The last issue concerns the nature of the third or doctoral cycle. EUA (2007: 28) report a mixture of patterns generally for doctoral programmes, with 49 per cent using a mix of taught course plus individual supervision; 29 per cent with doctoral schools established and 22 per cent relying on individual supervision alone. EUA (2007: 29) further comments that the speed of change in doctoral education ... amount(s) to a mini-revolution'. One issue, relevant to political science, concerns the mobility of doctoral students (EUA notes inadequate funding for mobility), while another relates to the market for qualified doctoral candidates (and here EUA notes the rise of the 'professional doctorate').

We have already noted that there is a general oversupply of suitably qualified doctoral candidates to fill academic posts in the discipline in many countries (Goldsmith, 2005: 65). As far as the doctoral labour market is concerned, how far do doctoral programmes in political science provide the kind of transferable research skills (generic and specific) that meet the labour market needs of government, the media, the voluntary sector as well as industry and commerce? Goldsmith (2005: 66) also raises concerns about what is expected of the doctoral student in terms of output and training.

Political science needs to concentrate attention on what sort of training it is providing at the doctoral level. Given there is not the space to develop arguments fully here, ${ }^{21}$ suffice it to say that in the authors' view only the best training is suitable for entry to the profession. And in providing such training, the 
profession is likely also to give students the generic transferable skills the general labour market is likely to search, notwith- standing the fact that there may well also be a market for more professionally orientated doctoral programmes.

\section{Notes}

1 For details see inter alia UNESCO (1950); Anckar and Berndtson (1987); Newton and Valles (1991); Quermonne (1996); Klingermann (2007). The IPSA Montreal conference in 2008 also contains a number of relevant papers see http://www.eleru.leru.org.

2 Again note the input of European countries into this development, especially that of the Nordic area, though the impact of the United States was probably greatest.

3 For further information see http://www.mundusmapp.org. See also the M.Sc. European Masters in Global Studies (http://www.uni-leipzig.de/gesi/emgs) offered by the Universities of Leipzig, Vienna, Wrocław and the London School of Economics or that in Human Rights and Democratisation (http:// www.emahumanrights.org/).

4 GEM stands for Globalisation, the European Union and Multilateralism. See http://www.erasmusmundusgem .eu/home.asp for further information. For more on GARNET, see http://www.garnet-eu.org/.

5 There is a wide range of VLEs available, some proprietary commercial software, such as Blackboard or WebCT, others provided on an Open Source basis like the University of Zurich's OLAT system.

6 PARLE stands for Politics Active Research Learning Environment.

7 For further information, see http//eleru.leru.org.

8 See Curtis and Blair (2010) for an overview of the issues surrounding placement learning.

9 For further information, see http://www.york.ac.uk/depts/poli/current/ug/casestudy.html.

10 Even this objective can be seen as linked to a government policy aimed at reducing the cost to the state of higher education overall.

11 The agreed elements are generally political theory/history of ideas; methodology (including statistics); political system of native country and of the EU; comparative politics; international relations; public administration and policy analysis; and political economy/political sociology.

12 Some details are provided by Furlong (2007).

13 Again the UK provides an interesting case. Its concern with standards and assessment, as evidenced by its quality assurance and teaching assessment programmes, revealed some examples of institutions and departments involved in some poor practice. Political science, however, emerged relatively unscathed from these exercises.

14 Weakness in foreign language training was one weakness identified in a recent international review of political science in the UK (BISA/PSA, 2007).

15 However, EUA (2007) reports mixed evidence on student mobility and suggests that shortening degree programmes may well mean fewer opportunities for student mobility, while improving conditions and standards in universities in Eastern Europe (currently major exporters of students under EU mobility schemes) may further reduce student mobility.

16 Journalism and management (mainly for the public sector) provide two examples of this kind of development.

17 But again the oversupply of qualified doctoral students remains a problem. For whom the profession is training doctoral students remains an unanswered question - see Goldsmith (2005).

18 Both authors have been described as excellent teachers from time to time. However, one would dismally fail most of the expectations of assessing bodies, while the other would no doubt be complimented on the presentation of his well-organised and documented work!

19 Education ministers have met every 2 years since 1999: Prague (2001); Berlin (2003); Bergen (2005); London (2007); Leuven (2009). Between times, work is undertaken on issues by the Bologna Follow Up Group, better known as BFUG. Tracking and understanding the ins and outs of the Bologna process is difficult and time consuming, if only because of the number of actors involved and because the detailed work is largely undertaken by BFUG. For an account see Reinalda and Kulesza (2006).

20 It is the Master's level that poses problems for the UK system under the Bologna agreement. BA degrees have traditionally been 3-year programmes (up to four if a year abroad or a work placement is involved) and Master's degrees have generally been of 1 year's duration.

21 See the contribution by Yves Meny below for a fuller discussion. 


\section{References}

Anckar, D. and Berndtson, E. (eds.) (1987) 'Introduction: Towards a study of the evolution of political science', International Political Science Review, The Evolution of Political Science 8(Special Issue): $5-7$.

BISA/PSA. (2007) 'International benchmarking review of UK political and international studies', available at www.psa.ac.uk.

Curtis, S. and Blair, A. (2010) (eds.) The Scholarship of Engagement for Politics, Birmingham: C-SAP, pp. 5-7.

Déloye, Y. and Mayer, N. (2008) 'French political science at a turning point', Paper presented to IPSA Congress: 'International Political Science: New Theoretical and Regional Perspectives', Montreal, 30 April - 2 May 2008.

European Universities Association (EUA). (2007) Trends V: Universities Shaping the European Higher Education Area, Brussels: EUA, (accessible via BFUG website).

Furlong, P. (2007) 'The European Conference of National Political Science Associations: Problems and Possibilities of Co-operation', in H.-D. Klingermann (ed.) The State of Political Science in Western Europe, Opladen'Farmington Hills: Barbara Budrich, pp. 401-407.

Goldsmith, M. (ed.) (2005) Doctoral Studies in Political Science - A European Comparison, Budapest: epsNet.

Klingermann, H.-D. (ed.) (2007) The State of Political Science in Western Europe, Opladen and Farmington Hills: Barbara Budrich.

Klingermann, H.-D. (2008) 'Capacities: Political science in Europe', West European Politics 31(1-2): 370-396.

Klingermann, H.-D., Kulesza, E. and Legulke, A. (eds.) (2002) The State of Political Science in Central and Eastern Europe, Berlin: Edition Sigma.

Newton, K. and Valles, J. (eds.) (1991) 'Political science in Western Europe, 1960-1990', European Journal of Political Research 20(Special Issue): 227.

Quermonne, J.-L. (ed.) (1996) 'La Science Politique en Europe: Formations, Cooperation, Perspectives', Final Report of a project supported by the European Commission, DG 12, Paris: Institut d'Etudes Politiques de Paris.

Reinalda, R. and Kulesza, E. (2006) The Bologna Process: Harmonizing Europe's Higher Education, Opladen: Barbara Budrich.

UNESCO. (1950) Contemporary Political Science, Paris: UNESCO.

\section{About the Authors}

Mike Goldsmith, ACSS, is Emeritus Professor of Politics at Salford University and Visiting Professorial Fellow at De Montfort University, UK. He has written and published extensively in the field of comparative local government and urban politics. His most recent publication, edited with Ed Page, is Changing Intergovernmental Relations, Routledge, 2010.

Chris Goldsmith is Senior Lecturer in Politics and International Relations at De Montfort University, having also taught in Tyumen State University in Siberia. His research interests and publications concern British foreign policy at the time of Suez. He has also published on teaching matters and is currently is a member of the NewSECEU Consortium and works with the UK body CSAP on politics teaching issues. 